\title{
Dual Specificity Mitogen-Activated Protein Kinase Kinase 1
}

National Cancer Institute

\section{Source}

National Cancer Institute. Dual Specificity Mitogen-Activated Protein Kinase Kinase 1. NCI Thesaurus. Code C17808.

Dual specificity mitogen-activated protein kinase kinase 1 (393 aa, $43 \mathrm{kDa}$ ) is encoded by the human MAP2K1 gene. This protein plays a role in protein phosphorylation and the MAP kinase signal transduction pathway. 